\title{
FOREWORD
}

\section{Writing History in a Globalising World}

\author{
FAHD KASUMOVIĆ* AND AMILA KASUMOVIĆ** \\ Faculty of Philosophy, University of Sarajevo
}

In the midst of global socioeconomic and political changes, when news on pandemics, wars and climate changes have become a regular part of the public information networks and our everyday lives, the Faculty of Philosophy of the University of Sarajevo and its History Department celebrate their $70^{\text {th }}$ anniversary. When this academic department was founded, in the mid- $20^{\text {th }}$-century Yugoslavia, social, political and cultural settings at both the global and the local stage looked fairly different than it is the case today. Although the globalisation process ${ }^{1}$ had been underway for quite some time, while interconnectedness and interdependence of the world was on the rise, its pace and impact on local communities in the Balkans was on a considerably lower level, partly because of the less intense information flow in comparison to the age which we now tend to call digital. On the other hand, on the local stage, political elites sought to modernise the economy and consolidate their control over the society, whilst one of the most important challenges that stood before them was the making of a new academic and educational network in the country that had previously not been "lucky" enough to develop its own modern university tradition. ${ }^{2}$ The History Department became an integral part of this new network from the early days of the University of Sarajevo, in $1950 .{ }^{3}$ Arguably, this year makes an important milestone in the social and intellectual history of Bosnia and Hercegovina. Among the events that changed the academic landscape of this country in the middle of the $20^{\text {th }}$ century, one might also mention the fact that the foundations for further development of higher education and history teaching were

"PhD. History Department. Email address: fahd.kasumovic@ff.unsa.ba

"PhD. History Department. Email address: amila.kasumovic@ff.unsa.ba

${ }^{1}$ For more information on the globalisation process and challenges it poses for the contemporary world, see Turner/Holton 2015; Steger 2017.

${ }^{2}$ By this we mean that there was no university tradition in Bosnia and Hercegovina. However, university tradition was present before that in the broader Yugoslav framework.

${ }^{3}$ For more information on the establishment of the Faculty of Philosophy in Sarajevo and its History Department, see Komšić 2010 (ed.), 5-12, 113-115. 
successfully laid, while the establishment of the History Department represented, additionally, a breaking moment for the historical scholarship in this Western Balkan country.

Having all this mind, the $70^{\text {th }}$ anniversary of the Faculty of Philosophy (November 11, 1950) and its History Department, is an excellent opportunity for the current department members to celebrate this foundation day as well as to show our deepest appreciation for the work of several generations of historians that previously covered these grounds. Owing to their untiring efforts, numerous history students were able to obtain their undergraduate, graduate and postgraduate degrees and honours, whilst their research contributions played a significant part in shaping the regional and local public discourses on the past and present. Additionally, it is worth mentioning that many professors from the History Department took an active role in the public life of their communities, while some managed to achieve international acclaim. All of them, in their own way, played a part in establishing and developing the reputation and academic identity of the History Department, the Faculty of Philosophy and the University of Sarajevo. ${ }^{4}$

Although acknowledging the contributions of our distinguished predecessors is a hardly avoidable topic in any academic talk on the history of the Faculty of Philosophy in Sarajevo, the focus of this foreword is not on the past, but on the future. To a great deal, this approach is the result of discussions at the History Department on how to effectively commemorate the anniversary of our mother institution and the foundation of our department. After long but fruitful consultations, the idea to publish a collection of scholarly articles in the English language gained support at the History Department as well as from the Faculty of Philosophy management. This is the first time our department has indulged in such an endeavour. It was decided that this publication was to include translations of the selected articles previously published in the Bosnian language, as well as new research papers written by the current department members. Together with this, the decision was reached that the results of these research efforts were to be presented to the public in a special issue of the Journal of the Faculty of Philosophy in Sarajevo (History, History of Art, Archeology), a yearbook published by the Faculty of Philosophy in Sarajevo.

By making this step, our goal is to bring our research and accomplishments to the attention of a broader audience. In doing so, we do not see this publication and our work as the end of the process, but quite the opposite - as the beginning which will allow our papers to be more visible in the academic field of History. Together with this, we expect it to serve as a catalyst for the future exchange of ideas and discussions that might ultimately improve the level of scholarly knowledge on the topics that

${ }^{4}$ For short biographies and the list of books published by the academic members of the History Department at Faculty of Philosophy in Sarajevo since 1950 to 2010, see Komšić 2010, 113-148. 
are being presented in this special issue of the Journal of the Faculty of Philosophy in Sarajevo (History, History of Art, Archeology). Moreover, we harbour hopes that this publication, together with similar collective ventures realised by our esteemed colleagues, will help us and our mother institution, the Faculty of Philosophy of the University of Sarajevo, to navigate more successfully through the increasingly globalising world of research and education. ${ }^{5}$ At least, these words speak of our academic enthusiasm as we certainly want to be a step closer to achieving this aim.

Choosing a title for this special issue has been a particularly demanding task as we wanted it to be connected to a common theme and not just a collection of unconnected articles. Owing to the fact that all of us have been committed to researching the history of Bosnia and Hercegovina, in the broader context of the Western Balkans, or the history of life and society on the territory which is now widely known under these names, the idea emerged to use this to our advantage. Hence, it was decided that a common theme, as well as the title of this publication, be as follows: Reflections on Life and Society in the Western Balkans: Studies in the History of Bosnia and Herzegovina.

This is an ambitious title which indicates a broader framework we want to embed our articles in-history of the society. Although this term is sometimes considered vague, it is still very much in use, while we consider it to be a useful concept in binding together our research contribution. Among many definitions of society that may be encountered in the academic literature, here, it has been conceived in its, arguably, broadest sense-multiple overlapping and intersecting socio-spatial networks of human relationships. ${ }^{6}$ Identifying, researching, interpreting and presenting to the public the data extracted from the primary historical sources on various human interactions that occurred in the region known today as Bosnia and Hercegovina and the Western Balkans, from the classical age to the contemporary history, is in the main focus of this special issue of the Journal of the Faculty of Philosophy in Sarajevo (History, History of Art, Archeology). Moreover, we aim at researching any data which could provide us with more knowledge on the conditions that influenced people's lives in the mentioned area. Obviously, such a

\footnotetext{
${ }^{5}$ For more information on the consequences of globalisation for research and higher education worldwide, see King et al. (eds.) 2011. Also, for information on the challenges of history writing in the global era, see Hunt 2014. However, although we value highly Hunt's ideas on history writing in the global era, it needs to be pointed out that our own understanding of this problem which is presented in this preface is developed through the years and not under her influence. As many of our colleagues, for years we have been reading, researching and trying to find the methodologically sound way to write history, even before we even started to think about the globalisation process.

${ }^{6}$ We have slightly modified the definition of society proposed by the acclaimed sociologist Michael Mann. While he speaks of the intersecting networks of power, we are more inclined to speak more broadly of the networks of human relationships. Of course, we do consider power to be an important element in these networks. For more information on this, see Mann 1986, 1.
} 
broad title defies any attempt to make even a provisional list of the subject matters which were of interest to us, so let us only say that our interests range from the interactions in the political and military field to the economy, ideology and culture in its broadest sense, with a remark that this is only a tip of the iceberg. Additionally, the articles in this special issue not only explore the past, but also historiographic ways of constructing the past, with paying a special attention to the possible ways of deconstructing the dominant images and stereotypes.

Having defined our goals in the aforementioned manner, it needs to be pointed out what our aim is not, as well as to provide several methodological remarks which may be important for understanding the articles published in this special issue, or at least some of them. First, this publication does not aim to create or reinforce national identities as traditional historians often did it in the Balkans, as well as in other regions of the world. As it has been stated before, the target audience is much broader than the peoples of the Balkans and it pretends to sail out to the global "seas of knowledge". Second, from a methodological point of view, the contributors of this special issue harbour independent ideas on writing history and every one of them is individually responsible for his/her own work and results. We have different approaches which are sometimes intersecting and on other occasions are divergent. However, this methodological diversity is not a disadvantage. On the contrary, we are more inclined to think of it as of a starting point for a future discussion, hopefully a fruitful one.

What is the current level of knowledge in the English-speaking world on the history of Bosnia and Hercegovina and how this publication might fit into the global repositories of historiographic literature? More than ever before, we see that a number of academic works in the English language which focus primarily on the history of Bosnia and Herzegovina is on a slow but a steady rise. Arguably, this fact provides the international reading public with a better opportunity to understand this part of the world, its peoples, social and political history as well as its cultural heritage. And this interest has suddenly grown during the 1990s, although it needs to be emphasised that even before this period, throughout the $20^{\text {th }}$ century, and especially since the 1970s, it was possible to find historiographic works on Bosnia and Herzegovina signed by researchers coming from distant parts of the world and influential academic centres (i.e. the USA). ${ }^{7}$ Nevertheless, a major leap in the international public's interest in Bosnia and Herzegovina occurred during the 1990s as Bosnia and Herzegovina became an independent state, while it was dragged into a bloody war which changed the face of this country once again. During this period, we encounter the first conferences in the West (Harvard, Massachusetts, 1993) focused

${ }^{7}$ For examples, see Fine 1975; Donia 1981. Together with these studies, the broader region of the Balkans was also of interest to historians. See Jelavich 1983. 
completely at providing an insight to the history of Bosnia and Herzegovina. The organisers aimed at providing the international observers of the conflict with a reliable information on the history of ethnic and religious groups that covered these grounds since the Middle Ages to the 1990 s. $^{8}$ After the war, similar collective efforts continued as a symposium on the history of Ottoman Bosnia was held in Sarajevo in 2001. This academic meeting, the proceedings of which were later published by the University of Wisconsin, had a strong international attendance, but it also included some of the leading local historians. ${ }^{9}$ Although these academic events were oriented more towards synthesis than to original research - which is why they faced a fair share of criticism - it is important to notice they both still managed to draw the attention of the world to Bosnia and Herzegovina and to instigate further scholarly discussion on the history of this area. As Noel Malcom, an acclaimed Oxford historian and one of the participants in the second of the mentioned conferences, rightfully pointed out "the cultural heritage of Ottoman Bosnia was, until the outbreak of the recent war both unusually rich and peculiarly neglected by the outside world". ${ }^{10}$

However, it would be wrong to assume that any conflict could trigger such a rise in interest by itself, without some kind of a mentality change which occurred on the global level. Arguably, one of the consequences of profound changes experienced in the last decade of the $20^{\text {th }}$ century in the developed countries was the rise of interest among academicians and leading publishing houses in the history of the various parts of the globe. ${ }^{11}$ The change is obvious as such societies have outgrown their traditional aspirations to research exclusively their own national histories. Therefore, in 1994, a concise history of Bosnia was published by Macmillan, ${ }^{12}$ while more than two decades after it, in 2015, another world-renowned publishing house, the Cambridge University Press, ${ }^{13}$ decided to present to the public another scholarly attempt at writing a concise history of Bosnia.

Without a doubt, writing short histories has become a trend in the globalising world. Owing to the fact that such historical syntheses provide us with a fast source of relevant academic information, they are usually warmly welcomed in the broader public. In spite of that, it still needs to be emphasised that such histories could hardly be called a hallmark of academic knowledge on the history of Bosnia. In our opinion, the most valuable contributions should be looked for elsewhere and,

${ }^{8}$ For a collection of papers presented at this conference, see Pinson (ed.) 1996.

${ }^{9}$ For a collection of papers presented at this conference Koller/Karpat (eds.) 2004.

${ }^{10}$ See Malcolm 2004, vii.

${ }^{11}$ For a short history of the Balkans, see Mazower 2000.

${ }^{12}$ See Malcolm 1994. Besides, in the same calendar years this book was also published by New York University Press. The interest for this book was evident during the following years as several editions are available on the market.

${ }^{13}$ See Carmichael 2016. 
most rightfully, in the studies rooted in the original research. R. Donia, R. Okey, E. Grable, M. Hickok, M. A. Hoare are only some of the historians who provided us with such research on the history of Bosnia and Hercegovina since the $1990 \mathrm{~s} .{ }^{14}$ Yet, it is clear now that books written by the said authors are only a tip of the iceberg as the number of research articles on the history of Bosnia published in the academic journals in the West is much greater and their exact number is hard to estimate. What has particularly come as a pleasant surprise to us is the fact that we have encountered new and interesting contributions in the history of Bosnia in some of the respected international journals where we least expected them to be published. We interpreted it as another sign that the history of Bosnia is being increasingly integrated into the global academic landscape.

Another important consequence of the globalisation in research and education is the fact that many of the leading academic centres in the West have opened their doors to talented people of different nationalities. We have witnessed recently that a handful of historians from the Balkans got their postgraduate degrees at renowned world universities; others managed to obtain scholarships and visiting fellowships, as well as to actively participate in the international research projects. Moreover, in some respected academic journals in the East and the West it is possible to find original research articles written by historians coming from the universities in Bosnia and Herzegovina. ${ }^{15}$ Throughout the last decade, this phenomenon has apparently become more visible than ever before. We believe that we are not wrong when we say that historians are going global too, with the rest of the academic world. What is sure is that the first and, arguably, the hardest steps have been made and predictions are that such a trend will continue in the near future. With a special joy, we are looking forward to seeing the number of such contributions grow even more.

Arguably, similarly to the mentioned authors, the biggest challenge we all face today in researching the history of Bosnia and Herzegovina is overcoming grand narratives ${ }^{16}$ inherited from the past as well as to adjusting our approaches to the raising academic standards and historiographic developments which reshaped our understanding of knowledge during the last few decades. And these new positive developments not

${ }^{14}$ For examples, see Donia 2006; Greble, E. 2011; Hoare 2003; Okey 2007; Hickock 1997.

${ }^{15}$ For an example of such a book written by a Bosnian author, which received positive revues, see Hajdarpasic 2015.

${ }^{16}$ Grand narrative (also master narrative or meta-narrative) is a narrative about other narratives which encompasses them and gives them historical meaning. In other words, it is a narrative schema which explains and orders knowledge. For example, in the Balkans, we have witnessed influential and totalising Marxist grand narratives on historical progress, meaning of history, and socio-economic formations which were emulated in historiography. Although the term master narrative is developed in critical theory, we can encounter it today in historiography too, which is a result of rising interdisciplinarity in the humanities. 
only require us to reassess the dominant narratives, but also to raise the level of selfcriticism and to show understanding of the disciplinary limits and various influences. What we have learned from major developments in the broader field of humanities is that we are all caught in the network of discourses ${ }^{17}$ that influences us as history writers through our education, social and cultural interactions. We acknowledge that that it is impossible to escape it, although it is possible and even desirable to strive to asses such influences in an attempt to raise our own self-understanding, self-criticism and the level of our history writing. Of course, all of this is hardly imaginable without overcoming the gap between theory and empirical research as well without advancing the use of interdisciplinary research methods in our studies. Although the methods we use are almost constantly being re-examined end re-evaluated, one thing still remains as the corner stone of our field-commitment to find our conclusions and our research on the basis of primary sources. Before the digital phase of the age of globalisation, as well as in the middle of it, that commitment has been a constant which will be with us as historians in the foreseeable future.

What are the grand narratives and stereotypes which presented the biggest challenge for the historians coming from other parts of the globe and to the historians raised and educated in Bosnia and Hercegovina? The list is long and this preface does not pretend to encompass them all, although we do feel that is necessary to mention at least some. For the Western authors, the greatest set of stereotypes that needs to be re-examined are the negative cultural representations of the Balkans as the European Other within, as it is geographically being inextricably a part of Europe. Owing to the efforts of $\mathrm{M}$. Todorova and a path-breaking study of E. Said, ${ }^{18}$ today we know a great deal on these cultural strategies and we are much better methodologically equipped to understand them and to explain them. The studies are important for all of us as they considerably helped us in improving our research of Bosnia in the regional context of the Balkans or Southeast Europe.

On the other hand, the dominant narratives that have traditionally imbued the history writing in Bosnia and Herzegovina, similarly as in the neighbouring countries, have been different although they partly overlap with the previouslydescribed leading narratives in Europe. Interestingly enough, the people in the Balkans themselves were inclined to negatively represent the Balkans, so this name has become undesirable in the countries situated in the Balkan peninsula. Todorova shared her thoughts on this matter and noticed that such a phenomenon occurred in various parts of the Balkans. Our own experiences confirm this notion. As students, and afterwards as young assistants at the History Department (Faculty of Philosophy in Sarajevo), in the late 1990s and during 2000s, we witnessed that the

\footnotetext{
${ }^{17}$ For a general insight into the notion of discourse, see Van Dijk 2008; Mills 2004.

${ }^{18}$ See Todorova 1997; Said 1994. Also see Goldsworthy 1998.
} 
name the Balkans was considered undesirable. Obviously, for many members of the academic community in Bosnia and Herzegovina this name carried a heavy load of negative representations which they wanted to escape.

As a result, our professors at that time mostly preferred the name Southeast Europe, which in the 1990s entered the curricula at the History Department. However, since then, the times have considerably changed, so after the consultations at our department, we decided to put the name the Balkans in the title for this special issue of the Journal of the Faculty of Philosophy in Sarajevo (History, History of Art, Archeology), whilst it needs to be pointed out that the label Southeast Europe is still dominant in our curricula. In a way, that is a statement that we accept both in terms of the broader region we live in. We are aware that both of them are culturally constructed, as any other geographical term, while there is a considerable disagreement about the boundaries of this region. Furthermore, we embrace the fact that the Balkans and the Southeast Europe in a broader social context may be connected with various sets of beliefs and representations. However, we do not see any of these discursive practices as fixed. Rather, we feel that they need to be explained, contextualised and, ultimately, deconstructed. Arguably, this is the way to rethink these terms and their applicability in the global age.

Together with these challenges, in today's Bosnia and Hercegovina, as well as in the broader region of the Western Balkans, we are facing a challenge of deconstructing some of the dominant national narratives on the history of the Balkans. Since the $19^{\text {th }}$ century, historiography in the Balkans was considered to be a tool for political elites to influence the national homogenisation, give ethno-confessional groups in the region a sense of belonging, construct them a shared memory, give them knowledge on their shared past and suggest to their co-nationals that they also need to have shared future and identities. Eventually, this led to some of the national myths that not only contradict to what we know from the primary sources, but also provide us with hegemonic mono-perspective views of the past, which deliberately exclude some of the "undesirable" historical perspectives from the "official" historiographic accounts.

We do not wish to negate the rights of various national groups to have their own collective memories as well as to share a special interest in some episodes of their past which they see as important for the their identities or for the history of their "imagined community". ${ }^{19}$ However, we do think that the future of history writing in the global age of increased communications and interdependence of the world lies in multiperspectivity, and not in any kind of a simplistic account of the past. By acknowledging the fact that history has left us a number of primary sources which contain evidence on various discourses and individual perspectives, which are often mutually conflicting, as well as by accepting the call to compare these conflicting narratives, we should also

${ }^{19}$ For a work which considers nation as imagined community, see Anderson 2006. 
accept that such an approach may enrich us all and may, hopefully, lead us to a better understanding of cultural diversity, as well as of the diversity of perceptions in the past and present. Of course, methodologically it is a more viable option to speak of "truths" which depend on the observers' point of views than about the absolute truth of traditional historians.

After presenting approaches of the selected historians from the West to the study of the history of Bosnia and Hercegovina, as well the challenges which stand before any historian wishing to embark on writing history in times we have recognised as the age of globalisation in research and education, we finally get to the part where we need to present the historiographical contributions that are being presented in this special issue of the Journal of the Faculty of Philosophy in Sarajevo (History, History of Art, Archeology).

Although we have established that, since the 1990s, the western historiographies have been recording a significant increase of interest in the history of Bosnia and Herzegovina, it needs to be emphasised that most papers in this field are still being written and published in Bosnia and Herzegovina, as well as in the broader region of the Western Balkans, or by the authors hailing from these parts of globe. Therefore, any further development of the historiographic knowledge in the history of Bosnia and Herzegovina is hardly imaginable without including research results of such authors into the global discussions on this matter.

Having such an aim in mind, this special issue of Radovi (i.e. the official name of the Journal of the Faculty of Philosophy in Sarajevo in the Bosnian language) presents twelve papers to the international public. Ten of them are English translations of original research articles and professional papers, previously published in the Bosnian language in various peer-reviewed academic journals and other publications. Together with them, this volume also includes two peer-reviewed original research articles, published here for the first time. The historiographic contributions contained in this special issue chronologically span from the classical antiquity to the contemporary age.

Amra Šačić Beća is the author whose paper opens the articles section in this special issue. The author's aim is to contribute to a better understanding of the past of Bosnia and Herzegovina in the classical antiquity by presenting and analysing four previously unpublished ancient epigraphic inscriptions. The monuments she chose to present were discovered near Trebinje and Doboj; they consist of a Roman milestone, votive altar, gravestone and a stamped brick. After reconstructing the text of the inscriptions, as well as dating them, Šačić Beća examines the possibilities for their use in writing history, with a special reference to the Roman provinces of Dalmatia and Pannonia.

Salmedin Mesihović proceeds with a study of two literary works by the famous Roman poet Ovid, with an aim of expanding the scope of historiographic knowledge 
on the Illyrian inhabitants of the Balkan peninsula in the classical antiquity. After examining Tristia, a collection of mournful elegies, as well as Epistulae ex Ponto, both written during Ovid's years-long exile at the Black Sea coast, Mesihović argues that these sources contain valuable information on Bato the Daesitiate, a leader of the $1^{\text {st }}$ century CE uprising against the Roman rule. Together with evaluating Ovid's views on the Illyricum, the author contextualises the mentioned texts and explains their significance for the broader field of Roman studies as well as for the Illyrian studies.

Esad Kurtovićs paper turns the spotlight on the history of Bosnia in the Middle Ages by exploring the archival materials and epigraphic inscriptions which testify to the fact that Vlachs in medieval Bosnia were also buried under the sepulchral monuments known widely as the stećak tombstones. The author notices that previous historiographic studies on this question have brought forth the mentioned hypothesis, but argues that such a claim has not been adequately supported with evidence and elaborated. This paper confirms the hypothesis and sheds more light on the mentioned phenomenon by presenting and evaluating the examples pertaining to the Vlach groups recorded in primary sources as the Vlahovići, Pliščići, Predojevići, Bobani and Drobnjaci.

Almir Peco choses to study the famous agreement between King Alfonso V of Aragon and Naples and Stjepan Vukčić Kosača, the Grand Duke of Bosnia, signed in 1444. Building on previous historiographic accounts of this matter, the author discusses the political reasoning which stood behind this interesting episode of the medieval diplomatic history, whilst also sharing his thoughts on the issue of its implementation. Moreover, he offers a new reading and translation of the mentioned document, based on a high-resolution facsimile from Archivo de la Corona de Aragón in Barcelona. This paper is published for the first time in this special issue of Radovi.

Fahd Kasumović shifts our attention to the Ottoman government's fiscal policy in the frontier regions of the Ottoman Empire, as well as to its interactions with the Roma people, by exploring the Gypsy poll tax policy in Bosnia. On the basis of primary sources from the archives in Turkey, Bulgaria and Bosnia and Herzegovina, this paper deconstructs the dominant historiographic narratives on this matter, opens up new research avenues and answers a handful of previously unaddressed questions. Throughout, the author argues that available historiographic accounts of this topic have failed to illustrate the changing nature of the Ottoman government's Gypsy poll tax policy, particularly its regional variations, whereas the necessary connections with broader transformation processes and fiscal crises were only touched upon. This paper aims at filling the mentioned gaps in historiography. It is published for the first time in this volume of Radovi.

Edin Radušic focuses on the investigation of British narratives about the beginning of the 1875-1878 uprising in Bosnia and Herzegovina, with an aim of 
assessing their place within the British public discourse, as well as the connection with the political strategies of the British government. By analysing the reports of the British consulate in Bosnia and Herzegovina, as well as newspaper articles, the author discerns the anti-Ottoman discourse in the British public and shows that it consisted of several inter-connected narratives: (i) oppression as a way of rule; (ii) oppression as the cause of the uprising, and (iii) the narrative on Turkish atrocities over Christians. Together with deconstructing these narratives, this paper shows the political instrumentalization in the British society, whilst also arguing that they played an important part in calls for a humanitarian intervention and western occupation of Bosnia and Herzegovina.

Amila Kasumović undertakes a challenging task of shedding more light on the history of Bosnia and Herzegovina under the Austro-Hungarian rule by analysing the activities of consular missions in Bosnia and Herzegovina in the first years of the Austro-Hungarian occupation. By deploying previously unused archival sources, this paper extends our knowledge on the functioning of the diplomatic networks in the mentioned area together with re-assessing the previous historiographic accounts on the legal position of Bosnia and Hercegovina, and, particularly, the views on the issue of consular jurisdiction. The author argues the sultan's sovereignty remained a dead letter, while the Austro-Hungarian policy towards foreign diplomatic missions shows that the Monarchy actively worked on strengthening its own rule on the newly occupied territory.

Minela Radušićs paper assesses the way in which the socialist historiography of Bosnia and Herzegovina perceived the unification of Yugoslavia, in 1918, by analysing selected works written by Hamdija Kapidžić, an acclaimed historian and professor at the University of Sarajevo. Together with evaluating Kapidžićs scholarly approach, including his arguments and conclusions, the author argues that his historiographic articles also bare visible traces of ideological influences as he was a man of his own epoch and space. The central part of this paper is focused on discussing the extent to which both can be observed in Kapidžićs work-a scholarly approach and ideologically-motivated historical revisionism.

Husnija Kamberovićs article raises the question of changes in centre-periphery relations in Socialist Yugoslavia during the 1960s by exploring the historical significance of the famous "Mostar consultations" of 1966, a political meeting of the Yugoslav communists, the aim of which was to discuss the current problems in West Herzegovina. On the basis of archival sources, the author argues that this event, as part of a broader political process, illustrates a policy shift in the ranks of the Communist Party as its prominent members admitted to have been following the wrong political course towards Croats in West Herzegovina. Moreover, the author presents his conclusions on the state centre's policy in integrating the periphery, its resolution to 
supress emigration and resistance, as well as to make changes which were expected to improve life chances of the Herzegovinian Croats in Yugoslav Federation.

Amir Duranovićs's article presents the results of the author's research on the $\mathrm{BiH}$ emigration to Germany in the second half of the $20^{\text {th }}$ century. The central part of this research is devoted to the examination of patterns by which the emigrant workers from Bosnia and Herzegovina, temporarily employed in Germany, created their identities. Throughout the article, the author argues that the relocation to a Western country whose socio-political context was significantly different in comparison with Socialist Yugoslavia, ultimately resulted in interesting identity transformations of the emigrant workers. Furthermore, this paper argues that emigrants' identities should be viewed as multi-layered phenomena which led the author to discern between these identity layers in an attempt to recognise and explain the transformations which occurred because of the relocation.

Zijad Šehić's paper turns the attention to the most recent history of Bosnia and Hercegovina, and to the political developments during the 1990s which decisively contributed to shaping the country's contemporary political reality-the Dayton Peace Agreement. On the basis of relevant literature and diplomatic sources, this paper examines the international plans and activities to end the war in the mentioned area between the Washington Agreement and the Dayton Peace Agreement. The article pays special attention to the events which led to a more active engagement of the USA in Bosnia. Additionally, the author evaluates the significance of this agreement for ending the war, but also argues that it did not allow the formation of a functional state, primarily because the ideologies that caused the war still continue to have a prominent role in the post-conflict society of Bosnia and Herzegovina.

Melisa Forić Plasto's paper closes this special issue of Radovi. Forić Plasto focuses her attention on the recent history textbooks in Bosnia and Hercegovina and comparatively analyses representations of the 1992-1995 period which they contain. This paper argues that different views of the war past, as well as the conflicting interpretations of committed war crimes and mass suffering, continue to deepen divisions among the school children as well. Together with the mentioned analysis, the author provides us with a valuable insight into the complexity of the current education system in Bosnia and Hercegovina as well as with the major challenges of history teaching in a post-conflict society.

Having provided a short insight into the content of contributions presented in this special issue of Radovi, we would like to properly acknowledge the contribution of colleagues and friends who generously helped us prepare this manuscript for publication. First, we would like to express our deepest gratitude to professor Muhamed Dželilović, Dean of the Faculty of Philosophy in Sarajevo. Without his understanding and support, this publication would not have been possible. Special 
thanks go to our colleague and friend Selma Đuliman, $\mathrm{PhD}$, from the Department of English Language and Literature, Faculty of Philosophy in Sarajevo, who translated nine out of twelve articles in this special issue. The article by Fahd Kasumović, as well as this Foreword, were written in English, while the articles by Amir Duranović and Zijad Šehić were translated by other translators engaged by the authors. Selma's proofreading and precious suggestions helped us improve the text. For all that, we are deeply grateful to her and consider ourselves lucky to have her on board as a part of the team. Also, we would like to thank all the staff at the Faculty of Philosophy and technical associates whose knowledge and efforts were essential to prepare this special issue for publication. And last but not least, we owe a great deal to many colleagues from the Faculty of Philosophy for their encouragement to bring this project to the end, as well as for stimulating discussions we had over the years. We appreciate this very much!

To recapitulate, writing history in a globalising word is a challenge as great as ever before. Although we are fully aware that there are multiple ways to answer this challenge, we argue that the future of the discipline lies in a constant reassessment of dominant paradigms, historiographic narratives, primary and secondary sources, scholarly methods, but, more importantly, ourselves, and our own cultural and social values, as well as of the disciplinary boundaries and limits of knowledge. What do we know and what it is possible to know with certainty, and where we should draw the line and consider the existence of parallel perspectives and parallel truths? As we accept this challenge, in a world that is increasingly inter-connected and inter-dependant, we should have in mind that the right way to go is to accept our differences and to think about historiography as of a playground for constant discussions, polemics and re-evaluations. We hope that articles contained in this special issue of the Journal of the Faculty of Philosophy in Sarajevo (History, History of Art, Archeology) will spark the interest of historians and other academicians at the broader international field, as well as that they will serve to instigate further discussions. Hopefully, we will all benefit from this, we in Bosnia, as well as other people interested in the history of Bosnia, in other parts of the world!

\section{Bibliography}

Anderson, B. 2006. Imagined Communities: Reflections on the Origin and Spread of Nationalism. London and New York: Verso.

Carmichael, C. 2016. A Concise History of Bosnia. Cambridge: Cambridge University Press.

Donia, R. J. 1981. Islam Under the Double Eagle: The Muslims of Bosnia and Hercegovina 1878-1914. New York: Columbia University Press. 
Donia, R. J. 2006. Sarajevo: A Biography. Ann Arbor, MI: University of Michigan Press.

Fine, J. 1975. The Bosnian Church: A New Interpretation: A Study of the Bosnian Church and Its Place in State and Society from the $13^{\text {th }}$ to the $15^{\text {th }}$ Centuries. New York and London: East European quarterly (distributed by Columbia University Press).

Greble, E. 2011. Sarajevo, 1941-1945: Muslims, Christians, and Jews in Hitler's Europe. Ithaca, NY: Cornell University Press.

Goldsworthy, V. 1998. Inventing Ruritania: The Imperialism of the Imagination. Yale University Press.

Hajdarpasic, E. 2015. Whose Bosnia? Nationalism and Political Imagination the Balkans, 1840-1914. Ithaca, NY: Cornell University Press.

Hickock, M. R. 1997. Ottoman Military Administration in Eighteenth-Century Bosnia. Leiden: Brill.

Hoare, M. A. 2003. The Bosnian Muslims in Second World War: A History. London: C. Hurst \& Co.

Hunt, L. 2014. Writing History in the Global Era. New York - London: W. W. Norton \& Company.

Jelavich, B. 1983. History of the Balkans, Cambridge: Cambridge University Press.

Komšić, I. (ed.) 2010. Spomenica 60. godišnjice Filozofskog fakulteta. Sarajevo: Filozofski fakultet.

Koller, M. and Karpat, K. (eds.) 2004. Ottoman Bosnia: A History in Peril. Madison: Center of Turkish studies, University of Wisconsin \& University of Wisconsin Press.

Malcolm, N. 1994. Bosnia: A Short History. London: Macmillan.

Malcolm, N. 2004. Preface. In: Ottoman Bosnia: A History in Peril, eds. Koller, M. and Karpat, K. Madison: Center of Turkish studies, University of Wisconsin \& University of Wisconsin Press, vii-viii.

Mann, M. 1986. The Sources of Social Power, 1. Cambridge: Cambridge University Press.

Mazower, M. 2000, The Balkans: A Short History. New York: Modern Library.

Mills, S. 2004. Discourse. London and New York: Routledge.

Okey, R. 2007. Taming Balkan Nationalism: The Habsburg "Civilizing Mission" in Bosnia 1878-1914. Oxford: Oxford University Press.

King R. et al. (eds.) 2011. Handbook on Globalization and Higher Education. Cheltenham, UK, and Northampton, MA: Edward Elgar Publishing Limited. 
Pinson, M. (ed.) 1996. The Muslims of Bosnia-Herzegovina: Their Historic Development from the Middle Ages to the Dissolution of Yugoslavia, Second Edition, Cambridge, Mass.: Centre for Middle Eastern Studies of Harvard University (distributed by Harvard University Press).

Said, E. W. 1994. Orientalism: Western Conceptions of the Orient. London: Penguin Books.

Steger, M. 2017. Globalization: A Very Short Introduction. Oxford: Oxford University Press.

Todorova, M. 1997. Imagining the Balkans. Oxford: Oxford University Press.

Turner, B. and Holton R. (eds.) 2015. The Routledge International Handbook of The Globalisation studies. London: Routledge.

Van Dijk, T. 2008. Discourse and Power. London: Palgrave Macmillan. 